\title{
PELAKSANAAN AKTIVITAS EKSTRAKURIKULER PASKIBRA (PASUKAN PENGIBAR BENDERA) DALAM PEMBENTUKKAN KARAKTER, MORAL DAN SIKAP NASIONALISME SISWA SMA NEGERI 3 SURAKARTA
}

\author{
Alan Sigit Fibrianto, Syamsul Bakhri \\ alansigitfibrianto53@gmail.com \\ Pascasarjana Universitas Sebelas Maret
}

\begin{abstract}
Senior High School 3 of Surakarta has a fairly high level of discipline, both in the timeliness of learning, giving sanctions decisive in cracking down on students who commit violations, an obligation to follow extracurricular activities, and so forth. Interesting for researchers to explore the implementation of extracurricular activities Paskibra closely with the principles of discipline in its efforts to foster nationalism. This study used descriptive qualitative method. The results showed that extracurricular activities Paskibra give effect to the formation of character, morality, and attitudes of the students because Paskibra can instill assertiveness, responsibility, discipline, confidence, and have a spirit of leadership, as well as within each program of extracurricular activities paskibra can foster aspect of nationalism that is, love the country, willing to sacrifice, unity and integrity, as well as the soul of the reformer or unyielding. So that students of Senior High School 3 of Surakarta can carry a sense of pride love of the homeland and nationalism which rests on four pillars of the nation (Constitution in 1945, Pancasila, Unity, and The Homeland), as well as three other pillars such as, Flag, Language, and Songs Nationality.
\end{abstract}

Keywords: Extracurricular, Forces Flag Raisers (Paskibra), Character, Morale, Attitude Nationalism.

\begin{abstract}
ABSTRAK
SMA Negeri 3 Surakarta memiliki tingkat kedisiplinan yang cukup tinggi, baik dalam ketepatan waktu pembelajaran, pemberian sanksi-sanksi tegas dalam menindak siswa yang melakukan pelanggaran, pewajiban mengikuti kegiatan ekstrakurikuler, dan lain sebagainya. Menarik bagi peneliti untuk menggali pelaksanaan aktivitas ekstrakurikuler Paskibra yang erat dengan prinsipprinsip disiplin dalam upayanya menumbuhkan sikap nasionalisme. Penelitian ini menggunakan metode deskriptif kualitatif. Hasil penelitian menunjukkan bahwa kegiatan ekstrakurikuler paskibra memberikan pengaruh terhadap pembentukan karakter, moralitas, dan sikap siswa karena paskibra dapat menanamkan sikap tegas, bertanggungjawab, disiplin, percaya diri, dan memiliki jiwa kepemimpinan, serta di dalam setiap pelaksanaan program kegiatan ekstrakurikuler paskibra dapat menumbuhkan aspek sikap nasionalisme yakni, cinta tanah air, rela berkorban, persatuan dan kesatuan, serta jiwa pembaharu atau pantang menyerah. Sehingga siswa-siswi SMA Negeri 3 Surakarta dapat mengemban rasa bangga akan cinta tanah air dan nasionalisme yang bertumpu pada 4 pilar bangsa (UUD 1945, Pancasila, Bhinneka Tunggal Ika, dan NKRI), serta 3 pilar lainnya seperti, Bendera, Bahasa, dan Lagu Kebangsaan. Khususnya pemahaman mengenai nilai-nilai yang terkandung di dalam pancasila sebagai pedoman hidup bangsa Indonesia.
\end{abstract}

Kata Kunci: Ekstrakurikuler, Pasukan Pengibar Bendera (Paskibra), Karakter, Moral, Sikap Nasionalisme. 
JURNAL MORAL KEMASYARAKATAN - VOL.2, NO.2, DESEMBER 2017 PELAKSANAAN AKTIVITAS EKSTRAKURIKULER PASKIBRA (PASUKAN PENGIBAR BENDERA) DALAM PEMBENTUKKAN KARAKTER, MORAL DAN SIKAP NASIONALISME SISWA SMA NEGERI 3 SURAKARTA

\section{PENDAHULUAN}

Sekolah merupakan wadah bagi setiap individu memperoleh pengetahuan. Selain pengetahuan, sekolah juga menjadi ajang dalam meraih berbagai prestasi baik di bidang ilmu pengetahuan, olah raga, ataupun kegiatan-kegiatan yang membawa nama baik sekolah melalui event-event tertentu, misal event kenegaraan. Di era globalisasi saat ini, identitas sebuah Negara menjadi hal yang sangat penting. Untuk menjaga Negara Indonesia dan selalu tetap pada jati dirinya, maka diperlukan sikap nasionalisme bagi seluruh rakyat Indonesia. Pemerintah selalu mengupayakan untuk menanamkan sikap-sikap nasionalisme terhadap masyarakat Indonesia.

Sikap nasionalisme dapat terinternalisasi pada setiap individu sejak di bangku sekolah. Maka dari itu, lembaga pendidikan bekerja sama dengan instansi-instansi sekolah untuk mulai menanamkan sikap-sikap nasionalisme. Implementasi sikap nasionalisme di dalam bangku sekolah dapat dilakukan dengan berbagai cara melalui kegiatan pendidikan. Misalnya saja, pemahaman sikap nasionalisme melalui mata pelajaran tertentu seperti mata pelajaran Pendidikan Kewarganegaraan (PKn), ada juga beberapa instansi sekolah yang menerapkan mata pelajaran khusus demi menumbuhkan jiwa nasionalisme seperti mata pelajaran Pancasila. Namun, sikap nasionalisme juga dapat diimplementasikan melalui berbagai macam kegiatan di sekolah. Kegiatan-kegiatan di sekolah tersebut biasa dikenal dengan sebutan ekstrakurikuler. Ada beragam ekstrakurikuler yang berada di dalam suatu instansi sekolah. Salah satu dari beberapa kegiatan ekstrakurikuler di sekolah yaitu, pasukan pengibar bendera (paskibra). Paskibra merupakan kegiatan yang mampu menanamkan sikap nasionalisme siswa, karena aktivitas kegiatannya sangat berhubungan atau sarat akan simbol-simbol kenegaraan, seperti bendera, upacara, baris-berbaris, dan sikap disiplin.

SMA Negeri 3 Surakarta merupakan Sekolah Menengah Atas yang terbilang favorit dan menjadi dambaan setiap masyarakat Kota Solo, bahkan di luar Kota Solo. Di Kota Solo terdapat beberapa SMA dalam kategori Negeri, antara lain: SMA Negeri 1 Surakarta, SMA Negeri 2 Surakarta, SMA Negeri 3 Surakarta, SMA Negeri 4 Surakarta, SMA Negeri 5 Surakarta, SMA Negeri 6 Surakarta, SMA Negeri 7 Surakarta, dan SMA Negeri 8 Surakarta. Namun, dari sekian banyak SMA Negeri tersebut, peneliti memilih SMA Negeri 3 Surakarta sebagai objek penelitian, karena di SMA Negeri 3 Surakarta merupakan salah satu SMA Negeri yang Paskibranya terbilang cukup bagus. SMA Negeri 3 Surakarta juga terbilang memiliki tingkat 
JURNAL MORAL KEMASYARAKATAN - VOL.2, NO.2, DESEMBER 2017 PELAKSANAAN AKTIVITAS EKSTRAKURIKULER PASKIBRA (PASUKAN PENGIBAR BENDERA) DALAM PEMBENTUKKAN KARAKTER, MORAL DAN SIKAP NASIONALISME SISWA SMA NEGERI 3 SURAKARTA

kedisiplinan yang cukup tinggi dalam mendidik setiap siswanya, baik dalam ketepatan waktu pembelajaran, pemberian sanksi-sanksi tegas dalam menindak siswa yang melakukan pelanggaran, pewajiban mengikuti kegiatan ekstrakurikuler, dan lain sebagainya. Setiap SMA Memiliki ragam ekstrakurikuler yang berbeda-beda. Namun, di dalam instansi dari masingmasing SMA Negeri di Surakarta memiliki yang namanya ekstrakurikuler Paskibra. Setiap SMA Negeri di Surakarta masing-masing memiliki segudang prestasi, baik di bidang akademik maupun di bidang non-akademik. Sebagai lembaga pendidikan formal, SMA Negeri di Surakarta berusaha untuk mengembangkan insan-insan cendekia yang unggul, berprestasi dan berkompeten dalam bidangnya. Hal ini dibuktikan dengan prestasi yang diraih baik akademis maupun nonakademis yang telah disumbangkan oleh para siswa baik dalam hal perlombaan individu maupun perkelompok atau tim di tiap-tiap sekolah. Sebagai sebuah institusi, beberapa SMA Negeri di Surakarta berusaha untuk mengembangkan potensi yang dimiliki siswa dalam menanamkan nilai-nilai patriotisme dan menumbuhkan jiwa nasionalisme, karena siswa merupakan aset yang sangat penting sebagai penerus bangsa. Dalam hal ini penanaman sikap nasionalisme dapat dikembangkan di dalam pendidikan ekstrakurikuler. Inilah yang juga peneliti rasa bahwa di SMA Negeri 3 Surakarta sangat condong terhadap beberapa pernyataan di atas.

Pendidikan ekstrakurikuler bertujuan untuk mengembangkan minat dan bakat serta mengembangkan potensi siswa. Salah satu kegiatan ekstrakurikuler yang memiliki peranan dan pengaruh dalam pembentukkan karakter, moralitas, serta menanamkan sikap nasionalisme adalah Pasukan Pengibar Bendera (Paskibra). Di SMA Negeri 3 Surakarta terdapat kegiatan ekstrakurikuler Paskibra. Dengan siswa mengikuti kegiatan ektrakurikuler Paskibra ini, maka diharapkan mampu untuk menumbuhkan jiwa nasionalisme, pembentukkan karakter dan moralitas siswa tersebut. Sehingga muncul sebuah pertanyaan yang dijadikan sebagai rumusan permasalahan di dalam penelitian ini yaitu, Bagaimana upaya yang dilakukan dalam aktivitas ekstrakurikuler Paskibra (Pasukan Pengibar Bendera) untuk menumbuhkan sikap nasionalisme, serta pembentukkan karakter dan moralitas siswa di SMA Negeri 3 Surakarta?

Adapun penelitian sebelumnya yang juga menyangkut judul yang diangkat oleh peneliti, yaitu: Penelitian oleh Suripto (2015) mengenai Pelaksanaan Ekstrakurikuler Paskibra (Pasukan Pengibar Bendera) dalam Upaya Menumbuhkan Sikap Nasionalisme Siswa di SMP Negeri 3 Malang. Hasil penelitian menunjukkan bahwa kegiatan ekstrakurikuler paskibra memberikan 
JURNAL MORAL KEMASYARAKATAN - VOL.2, NO.2, DESEMBER 2017 PELAKSANAAN AKTIVITAS EKSTRAKURIKULER PASKIBRA (PASUKAN PENGIBAR BENDERA) DALAM PEMBENTUKKAN KARAKTER, MORAL DAN SIKAP NASIONALISME SISWA SMA NEGERI 3 SURAKARTA

pengaruh terhadap pembentukan karakter dan sikap siswa karena paskibra dapat menanamkan sikap tegas, bertanggungjawab, disiplin, percaya diri, dan memiliki jiwa kepemimpinan, serta di dalam setiap pelaksanaan program kegiatan ekstrakurikuler paskibra dapat menumbuhkan aspek sikap nasionalisme yakni cinta tanah air, rela berkorban, persatuan dan kesatuan, serta jiwa pembaharu atau pantang menyerah. Sehingga siswa-siswi SMP Negeri 3 Malang dapat mengemban rasa bangga akan cinta tanah air dan nasionalisme yang bertumpu pada nila-nilai pancasila sebagai pedoman hidup bangsa Indonesia.

Mengenai konsep Nasionalisme secara etimologis berasal dari kata nation (bahasa inggris) yang artinya "bangsa", dan nasci (bahasa lain) yang artinya "dilahirkan". Orientasi nasionalisme adalah Negara kebangsaan, cinta nasionalisme lebih terarah kepada sesama bangsa. Nasionalisme berarti bangsa yang bersatu karena faktor kelahiran yang sama. Menurut Omensen (2012) Pengertian nasionalisme mengalami perkembangan beragam secara keseluruhan dapat diklasifikasikan menjadi tiga pengertian. Pertama, nasionalisme adalah idiologi sekaligus merupakan bentuk dari perilaku. Kedua, nasionalisme adalah sebuah cita-cita yang ingin memberi batas antara kita yang sebangsa dengan mereka bangsa lain. Ketiga, nasionalisme adalah ibarat mata koin yang mempunyai dua sisi, sisi pertama adalah politik dan sisi lainnya adalah etnisitas atau kesukubangsaan. Menurut Santoso (2014) Nasionalisme Indonesia merupakan suatu gerakan yang muncul sejak abad ke-19 dan awal abad ke-20. Gerakan ini bertujuan untuk mewujudkan manusia Indonesia menjadi sebuah bangsa yang merdeka dan berdaulat. Gerakan ini juga terjadi diseluruh negara-negara terjajah di Asia dan Afrika. Bangsabangsa di Asia dan Afrika seperti India, Mesir, Persia serta Indonesia sudah pernah mengalami masa kejayaansebelum masuk dan berkembangnnya imperialisme dan kolonialisme Barat.

Menurut Musa (2010) Nasionalisme mengandung nilai-nilai sebagai berikut, antara lain:

a. Persatuan

Cinta tanah air berimplikasi pada setiap orang berkewajiban menjaga dan memelihara semua yang ada diatas tanah airnya, sehingga muncul kesadaran akan pentingnya persatuan dan kesatuan bangsa. Persatuan inilah yang menurut Bung Hatta sebagai prinsip nasionalisme yang pertama. Kemudian prinsip ini pula yang memotivasi bangsa untuk bersatu padu dan berlomba-lomba memajukan Indonesia melalui nilai-nilai pendidikan. 
JURNAL MORAL KEMASYARAKATAN - VOL.2, NO.2, DESEMBER 2017 PELAKSANAAN AKTIVITAS EKSTRAKURIKULER PASKIBRA (PASUKAN PENGIBAR BENDERA) DALAM PEMBENTUKKAN KARAKTER, MORAL DAN SIKAP NASIONALISME SISWA SMA NEGERI 3 SURAKARTA

\section{b. Pembebasan dan Perjuangan}

Nasionalisme merupakan kemerdekaan perseorangan dari kekuasaan atau pembebasan manusia dari penindasan perbudakan. Nasionalisme dalam konteks inilah yang membangun segenap keadaan realita manusia tertindas menuju manusia yang utuh. Ketertindasan yang berawal dari rendahnya daya pikir dan wawasan yang bermuara pada rendahnya kualitas pendidikan, sehingga mudah dipecundangi bangsa asing.

c. Patriotisme

Patriotisme adalah semangat cinta tanah air, sikap seseorang yang bersedia mengorbankan segala-galanya untuk kejayaan dan kemakmuran tanah airnya.

Kemudian, mengenai konsep Aktivitas Kegiatan Ekstrakurikuler, istilah kegiatan ekstrakurikuler itu sendiri mengandung pengertian yang menunjukkan segala macam aktifitas di sekolah atau lembaga pendidikan yang dilaksanakan di luar jam pelajaran. Kegiatan ekstrakurikuler merupakan kegiatan yang menampung segala bakat dan minat dari peserta didik dalam mengembangkan potensinya dan juga melatih untuk mengemban tugas serta tanggung jawab dari individu. Sedangkan konsep aktivitas, Menurut Kamus Besar Bahasa Indonesia, Aktivitas artinya adalah segala bentuk kegiatan, keaktifan dan kesibukan seseorang untuk melaksanakan sesuatu jadi kegiatan yang dilakukan fisik atau non fisik adalah aktivitas. Aktif berarti sibuk melakukan sesuatu. Aktivitas sebagai suatu kegiatan atau kesibukan. Jadi aktivitas dapat juga disebut sebagai sebuah kegiatan/ kesibukan yang dilakukan seseorang dalam kegiatan sehari-hari. Aktivitas juga dapat diartikan sebagai suatu upaya melakukan suatu kegiatan tertentu secara aktif, aktivitas menunjukan adanya kebutuhan untuk aktif bekerja atau melakukan kegiatan-kegiatan tertentu. Menurut Peraturan Menteri Pendidikan dan Kebudayaan Republik Indonesia Nomor 62 Tahun 2014 Tentang Pengertian Ekstrakurikuler menjelaskan bahwa ekstrakurikuler atau yang biasa disingkat ekskul merupakan suatu kegiatan yang dilakukan diluar jam pelajaran baik di dalam maupun diluar lingkungan sekolah dalam rangka memperluas pengetahuan, meningkatkan keterampilan, dan menginternalisasikan nilai-nilai atau aturanaturan agama serta norma-norma sosial baik lokal, nasional, maupun global untuk membentuk insan yang sepenuhnya. Pengertian ekstrakurikuler yang dibatasi menurut Peraturan Menteri Pendidikan dan Kebudayaan yaitu:

"Kegiatan ekstrakurikuler adalah kegiatan di luar jam pelajar biasa dan pada waktu libur di sekolah, yang dilakukan baik di sekolah ataupun di luar sekolah dengan tujuan untuk 
JURNAL MORAL KEMASYARAKATAN - VOL.2, NO.2, DESEMBER 2017 PELAKSANAAN AKTIVITAS EKSTRAKURIKULER PASKIBRA (PASUKAN PENGIBAR BENDERA) DALAM PEMBENTUKKAN KARAKTER, MORAL DAN SIKAP NASIONALISME SISWA SMA NEGERI 3 SURAKARTA

memperluas pengetahuan siswa, mengenal antara berbagai mata pelajaran, menyalurkan bakat dan minat serta melengkapi daya upaya pembinaan manusia seutuhnya" (Depdikbud, 1978: 35-36).

Ekstrakurikuler yaitu, sebuah kegiatan pendidikan yang dilakukan diluar jam pelajaran tatap muka. Kegiatan tersebut dilakukan di dalam ataupun di luar lingkungan sekolah. Hal ini dilakukan dalam rangka meningkatkan pengetahuan, meningkatkan keterampilan, dan menginternalisasi nilai atau aturan-aturan agama serta norma-norma sosial, baik lokal maupun global untuk membentuk insan yang paripurna. Dengan ini ektrakurikuler merupakan kegiatan pendidikan diluar jam pelajaran yang ditujukan untuk membantu perkembangan peserta didik sesuai kebutuhan, potensi, bakat, dan minat mereka melalui kegiatan-kegiatan yang khusus diselenggarakan oleh pendidik dan atau tenaga kependidikan yang berkemampuan dan berwenang di sekolah.

Selanjutnya, mengenai pengertian Pasukan Pengibar Bendera (Paskibra) yaitu, merupakan pasukan pengibar bendera yang dilaksanakan oleh generasi muda yakni siswa-siswi yang ada di sekolah. Dalam salah satu materi pembinaan kesiswaan, yang tercantum dalam keputusan Menteri Pendidikan dan Kebudayaan dengan No. 0416/U/1984 yaitu tentang pendidikan pendahuluan bela negara yang diselenggarakan di sekolah. Kegiatan tersebut meliputi berbagai jenis kegiatan, antara lain dengan pembentukan Pasukan Pengibar Bendera (paskibra) sekolah yang meliputi berbagai jenis kegiatan, diantaranya Peraturan Baris Berbaris (PBB), Tata Upacara Bendera (TUB), serta Latihan Kepemimpinan Siswa Tingkat Perintis dan Pemula. Andro Mediawan menyebutkan bahwa "Ekskul Paskibra memiliki beberapa program kerja untuk dilaksanakan". Adapun beberapa program kerja paskibra tersebut untuk mewujudkan sumber daya manusia yang unggul dalam prestasi dan mengarahkan dengan baik, menyelenggrakan pendidikan yang mampu menyiapkan kader bangsa yang berwawaswanm keuanggulan dan santun dalam bermasyrakat, mengadakan evaluasi kerja, mengadakan latihan-latihan kader paskibra, membantu wilayah dalam pelaksanaaan upacara bendera atau peringatan hari besar, membina siswa-siswi yang berbakat dalam kepaskibraan, mengadakan latihan satuan, latihan satuan gabungan, maupun latihan gabungan, terakhir adalah berpartisipasi dalam setiap pelaksanaan kegiatan yang diselenggarakan (Mediawan, 2012: 131).

Selain itu, terkait dengan pembentukkan karakter dan moral merupakan dampak yang ditimbulkan dari beberapa aspek yang diperoleh atau dialami oleh masing-masing individu 
JURNAL MORAL KEMASYARAKATAN - VOL.2, NO.2, DESEMBER 2017 PELAKSANAAN AKTIVITAS EKSTRAKURIKULER PASKIBRA (PASUKAN PENGIBAR BENDERA) DALAM PEMBENTUKKAN KARAKTER, MORAL DAN SIKAP NASIONALISME SISWA SMA NEGERI 3 SURAKARTA

ataupun kelompok melalui pengalaman baik secara individu maupun kelompok. Emile Durkheim (1970) mengemukakan mengenai pengertian moralitas yaitu, meliputi konsistensi, keteraturan tingkah laku: Apa yang menjadi moral hari ini akan menjadi moral esok hari. Moralitas juga selalu meliputi pengertian wewenang: Kita dipaksa untuk bertindak dengan cara-cara tertentu; kita merasakan perlawanan terhadap impuls-impuls yang tidak masuk akal. Nah, kedua ciri moralitas ini -keteraturan tingkah laku dan wewenang- sebenarnya merupakan dua aspek dari satu hal yaitu, disiplin. (Penyatuan aspek-aspek yang berbeda atau bertentangan dari realitas dalam sebuah konsepsi adalah suatu kiat yang digemari Durkheim. Dia juga menggunakan prosedur yang terbalik. Sebuah konsep, misalnya bunuh diri, dibagi lagi atau dikualifikasi sehingga memberikan suatu klasifikasi lengkap dan eksklusif dari fenomena yang diselidiki itu). Jadi, unsur pertama moralitas adalah disiplin, yang dibentuk oleh keteraturan tingkah laku dan wewenang. Moralitas berarti suatu orientasi aktivitas yang impersonal. Tindakan demi kepentingan diri sendiri tidak pernah dianggap bersifat moral. Tetapi jika perilaku yang dianggap bersifat moral tidak diorientasikan kepada diri sendiri, objek manakah yang pantas menjadi fokusnya? Karena orang lain tidak dapat menuntut secara sah kepuasan yang, jika ditujukan kepada diri kita sendiri, akan bersifat amoral, maka objek perilaku moral haruslah sesuatu yang berada di luar diri seseorang, atau di luar sejumlah orang dari sejumlah orang lain.

Dengan demikian yang menjadi objek perilaku moral adalah kelompok, atau masyarakat. "Bertindak secara moral berarti bertindak demi kepentingan kolektif...bidang moral mulai di mana bidang sosial mulai." (Durkheim, 1925: 68). Jadi, kita sampai pada unsur kedua dari moralitas: keterikatan pada, atau identifikasi dengan kelompok. Sekali lagi, kedua unsur moralitas ini adalah dua aspek dari satu hal yaitu, masyarakat. Disiplin adalah masyarakat yang dilihat sebagai ayah, yang memerintah kita, yang mendorong kita melakukan kewajiban. Keterikatan pada kelompok mengimplikasikan masyarakat sebagai ibu, citra kebaikan, yang menarik hati kita. Unsur ketiga dari moralitas adalah otonomi. Jika perilaku demi kepentingan diri sendiri harus dianggap sebagai amoral, demikian juga halnya dengan perilaku yang mengingkari otonomi si pelaku, sebab, perilaku yang dibatasi adalah bukan perilaku yang baik. Padahal Durkheim sangat menekankan sifat memaksa dari kedua unsur pertama moralitasdisiplin dan komitmen kepada kelompok. Bagaimana ia memecahkan dilema ini? Pemecahannya ialah pengetahuan yang dapat diandalkan. Perbedaan antara menentukan sendiri (self 
JURNAL MORAL KEMASYARAKATAN - VOL.2, NO.2, DESEMBER 2017 PELAKSANAAN AKTIVITAS EKSTRAKURIKULER PASKIBRA (PASUKAN PENGIBAR BENDERA) DALAM PEMBENTUKKAN KARAKTER, MORAL DAN SIKAP NASIONALISME SISWA SMA NEGERI 3 SURAKARTA

determination) dan penundukan diri (submission) terletak pada kemampuan untuk meramalkan secara tepat konsekuensi dari berbagai alternatif tindakan. Otonomi menyangkut keputusan pribadi dengan mengetahui sepenuhnya konsekuensi-konsekuensi dari berbagai tindakan itu. jadi, pengetahuan terhadap hukum moralitas akan meningkatkan otonomi (Durkheim, 1997: 32). Durkheim juga mengaitkan antara pendidikan dan moral, di mana pendidikan sangat penting dalam menciptakan manusia sebagai makhluk yang bermoral. Kata Durkheim "Itulah tugas dan kemuliaan pendidikan". Pendidikan bukan hanya masalah memungkinkan seorang individu berkembang sesuai dengan kodratnya, atau hanya menyingkapkan segala kemampuan tersembunyi pada si individu yang menunggu penampakannya. Pendidikan menciptakan makhluk baru (Elle cree dans l'homme un etre nouveau) (Durkheim, 1922: 51).

Adapun teori yang digunakan peneliti dalam melakukan penelitian yaitu, Teori Fungsionalisme Struktural dari Talcott Parsons. Teori digunakan dengan maksud sebagai landasan dan pembuktian dari hasil akhir penelitian.

Gagasan Parsons tentang struktur dan sistem A.G.I.L. Fungsi adalah "Suatu gugusan aktifitas yang diarahkan untuk memenuhi satu atau beberapa kebutuhan sistem". Parsons dalam Ritzer mempercayai bahwa ada empat faktor fungsional yang diperlukan seluruh sistem. Secara bersama-sama keempat faktor fungsional tersebut dikenal sebagai skema A.G.I.L. Agar bertahan hidup, sistem harus menjalankan keempat fungsi tesebut:

1. Adaptasi adalah sistem harus mengatasi kebutuhan situasional yang datang dari luar. Ia harus beradaptasi dengan lingkungan dan menyesuaikan lingkungan dengan kebutuhankebutuhannya.

2. Goal attainment (pencapaian tujuan) adalah sistem harus mendefinisikan dan mencapai tujuan-tujuan utamanya.

3. Integrasi adalah suatu sistem yang harus mengatur antarhubungan bagian-bagian dari komponennya. Ia pun harus mengatur hubungan antar ketiga faktor fungsional lainnya (A, G, L).

4. Latensi (Pemeliharaan Pola) adalah sistem harus melengkapi, memelihara, dan memperbaharui motivasi individu dan pola-pola budaya yang menciptakan dan mempertahankan motivasi tersebut (Ritzer, 2012: 257).

Berikut kerangka berpikir dalam penelitian ini: 


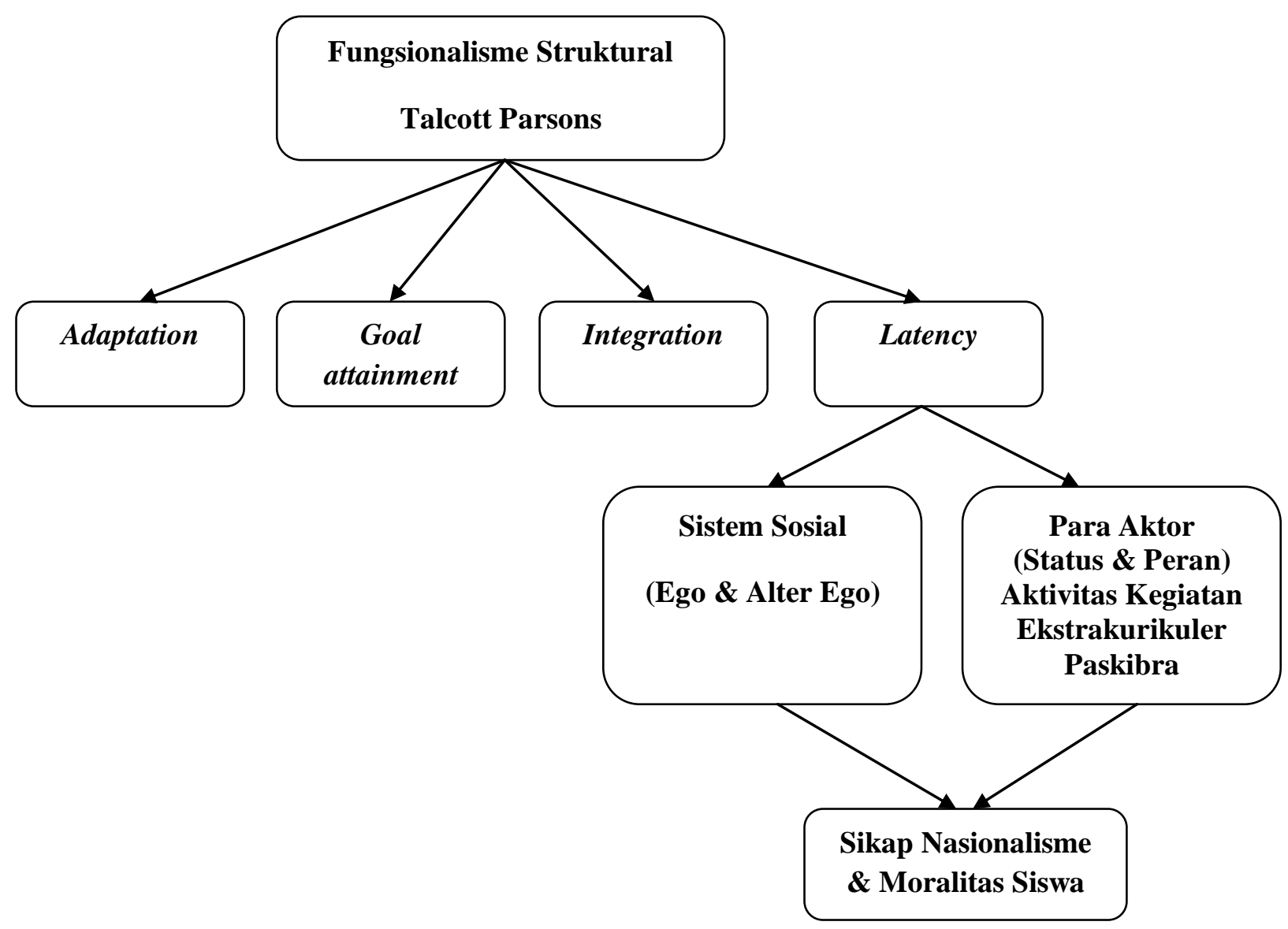

Gambar 1.1 Kerangka Berpikir di dalam Penelitian

Dari kerangka berpikir tersebut, peneliti menggunakan teori fungsionalisme struktural dari Talcott Parsons, dengan konsep A.G.I.L-nya. Dari keseluruhan konsep A.G.I.L milik Talcott Parsons, sebenarnya berhubungan dengan permasalahan yang diangkat oleh peneliti di dalam penelitian ini. Pertama, konsep Adaptation atau yang dikenal dengan adaptasi, di mana terdapat penyesuaian individu di dalam kegiatan ekstrakurikuler Paskibra di sekolah, sehingga individu atau siswa harus menyesuaikan dengan sistem atau dalam hal ini mampu beradaptasi dengan segala hal yang terdapat di dalam kegiatan ekstrakurikuler Paskibra. Kedua, Goal attainment atau pencapaian tujuan, di mana setiap individu yang tergabung di dalam kegiatan ekstrakurikuler Paskibra di sekolah memiliki visi dan misi ataupun tujuan yang ingin dicapai secara bersama-sama. Ketiga, Integration atau integrasi, di mana di dalamnya terdapat penyatuan unsur-unsur berbeda menjadi atau yang menghasilkan pola dan memiliki keserasian fungsi, sehingga siswa sama-sama dibentuk dengan kesamaan perilaku melalui persatuan di dalam 
JURNAL MORAL KEMASYARAKATAN - VOL.2, NO.2, DESEMBER 2017 PELAKSANAAN AKTIVITAS EKSTRAKURIKULER PASKIBRA (PASUKAN PENGIBAR BENDERA) DALAM PEMBENTUKKAN KARAKTER, MORAL DAN SIKAP NASIONALISME SISWA SMA NEGERI 3 SURAKARTA

keanggotaan Paskibra. Keempat, Latency atau yang dikenal dengan pemeliharaan pola, di mana di dalamnya terdapat istilah menjaga serta mempertahankan norma-norma dan nilai-nilai di dalam ruang lingkup tertentu, hal ini berkaitan dengan penanaman pola bagi setiap individu di dalam kegiatan ekstrakurikuler Paskibra agar tercipta keteraturan sesuai dengan sistem dan pola yang telah ada.

Namun, peneliti lebih memandang pada satu sudut pandang tertentu yang menjadikan penekanan dalam pembuktian dari penelitian ini dengan memfokuskan kepada salah satu konsep AGIL yaitu, Latency atau pemeliharaan pola. Alasan peneliti memilih konsep Latency yaitu, karena di dalam ekstrakurikuler Paskibra terdapat pola yang dipelihara yang sudah ada sebelumnya dan diterapkan secara statis oleh sistem kepada keanggotaan Paskibra. Jadi, setiap individu di dalamnya memiliki kesamaan tujuan dan pola kegiatan dan terus ditanamkan pada generasi yang selanjutnya. Dalam hal ini, berarti terdapat pola-pola yang dipelihara di dalam kegiatan Paskibraka yang diaplikasikan melalui aktivitas ekstrakurikuler Paskibra di sekolah.

Selain itu, peneliti juga mengkaitkan dengan konsep pemikiran Parsons antara sistem sosial dan para aktor yang nantinya terdiri dari status dan peran di dalam sistem sosial. Di dalam sistem sosial, Parsons mengemukakan dua konsep yaitu, antara ego dan alter ego. Ego yang berarti suatu tindakan yang dilakukan individu pada ruang lingkup tertentu karena kesadaran pribadi. Sedangkan, alter ego yang berarti suatu tindakan yang dilakukan individu bukan karena kesadaran pribadi, melainkan karena adanya pengaruh dari sistem sosial di dalam ruang lingkup tertentu, artinya individu melakukannya atas dasar pembentukan dari sistem sosial yang mengharuskan dia melakukan hal yang seharusnya dilakukan, artinya kita harus mengikuti sistem dan bukan atas dasar kehendak kita sendiri.

Selanjutnya, konsep yang lain yaitu, para aktor di dalam sistem sosial, yaitu terdapat peran dan fungsi masing-masing individu di dalam sistem sosial. Terjadi pemindahan norma-norma dan nilai-nilai suatu sistem kepada para aktor di dalam sistem itu sesuai dengan peran dan status yang dimiliki masing-masing individu di dalamnya. Dalam proses sosialisasi yang berhasil, norma-norma dan nilai-nilai diinternalisasikan, yakni norma-norma dan nilai-nilai itu menjadi bagian dari "suara hati" para aktor, di mana pada akhirnya akan menciptakan suatu pembentukkan karakter, moralitas, dan sikap nasionalisme yang kuat pada setiap aktor yang terlibat di dalamnya. 
JURNAL MORAL KEMASYARAKATAN - VOL.2, NO.2, DESEMBER 2017 PELAKSANAAN AKTIVITAS EKSTRAKURIKULER PASKIBRA (PASUKAN PENGIBAR BENDERA) DALAM PEMBENTUKKAN KARAKTER, MORAL DAN SIKAP NASIONALISME SISWA SMA NEGERI 3 SURAKARTA

\section{METODE}

Penelitian ini menggunakan metode kualitatif, yaitu dengan pendekatan deskriptif kualitatif. Penelitian dengan metode deskriptif kualitatif adalah penelitian yang bertujuan untuk menjelaskan berbagai kondisi, berbagai situasi, serta mendeskripsikan berbagai realita sosial yang ada dalam masyarakat, lalu kemudian mengangkat ke permukaan tentang karakter ataupun gambaran tentang kondisi dan sesuatu tertentu (Bungin, 2015: 36).

Lokasi penelitian dilakukan di SMA Negeri 3 Surakarta. Adapun alasan lokasi penelitian di SMA Negeri 3 Surakarta, dikarenakan SMA Negeri 3 Surakarta tersebut di dalamnya memiliki salah satu kegiatan ekstrakurikuler yaitu, Paskibra (Pasukan Pengibar Bendera). Selain itu, karena lokasi dari sekolah tersebut juga mudah diakses karena lokasinya yang tidak jauh dari lokasi tempat tinggal peneliti, dan berada di pusat kota. Maka dari itu, peneliti menetapkan SMA Negeri 3 Surakarta tersebut sebagai lokasi penelitian.

Populasi dalam penelitian ini adalah siswa/i anggota Paskibra di SMA Negeri 3 Surakarta. Populasi adalah wilayah generalisasi yang terdiri dari objek atau subjek yang mempunyai kuantitas dan karakteristik yang ditetapkan oleh peneliti untuk dipelajari, dan kemudian ditarik suatu kesimpulannya. Target dari penelitian ini adalah untuk melihat bagaimana aktivitas kegiatan ekstrakurikuler Paskibra mempengaruhi sikap Nasionalisme siswa.

Menurut Bungin sebagian dari jumlah populasi yang dipilih dari sumber data disebut sampel. Jumlah populasi akan mempengaruhi jumlah sampel penelitian (Bungin, 2005: 11). Dalam penelitian ini peneliti menggunakan purposive sampling dalam pengambilan sampel yaitu, teknik pengambilan sampel yang disesuaikan dengan tujuan penelitian. Sampel adalah sebagian populasi yang diambil dengan menggunakan cara-cara tertentu. Maka peneliti memutuskan untuk mengambil delapan orang dari populasi sebagai sampel dalam penelitian ini.

Sumber data terbagi menjadi dua yaitu, sumber data primer dan sumber data sekunder. Data Primer merupakan data yang langsung diperoleh dari kegiatan penelitian di lapangan dengan melakukan pengamatan. Selain itu peneliti juga melakukan wawancara dan hasil dari wawancara inilah yang merupakan data utama di dalam penelitian ini. Data sekunder adalah data yang diperoleh secara tidak langsung dari objek penelitian. Pengumpulan data sekunder dalam penelitian ini berupa keadaan geografis, dan berupa kegiatan mahasiswa yang didapat dari dokumen atau profil kampus, buku-buku/ studi kepustakaan (Library Research), dan internet. 
JURNAL MORAL KEMASYARAKATAN - VOL.2, NO.2, DESEMBER 2017 PELAKSANAAN AKTIVITAS EKSTRAKURIKULER PASKIBRA (PASUKAN PENGIBAR BENDERA) DALAM PEMBENTUKKAN KARAKTER, MORAL DAN SIKAP NASIONALISME SISWA SMA NEGERI 3 SURAKARTA

Lalu, untuk pengolahan data dan analisis data yaitu, diperoleh dari data lapangan seperti hasil wawancara dengan beberapa informan sebagai data primer dan dari beberapa hasil yang diperoleh dari data sekunder, maka peneliti akan melakukan deskripsi data dengan memaparkan secara naratif hasil dari data yang diperoleh serta melakukan kajian mengenai sikap nasionalisme, pembentukkan karakter dan moralitas, melalui aktivitas dalam kegiatan Pasukan Pengibar Bendera (Paskibra), dengan teori dari Talcott Parsons yaitu Fungsionalisme Struktural dengan menggunakan konsep A.G.I.L (Adaptation, Goal attainment, Integration, Latency) sebagai pisau analisis di dalam penelitian ini.

\section{HASIL DAN PEMBAHASAN}

Penelitian dilakukan di SMA Negeri 3 Surakarta karena memiliki salah satu kegiatan ekstrakurikuler yaitu, Paskibra (Pasukan Pengibar Bendera). Selain itu, lokasi sekolah tersebut mudah diakses karena berada di pusat kota. Lokasi SMA Negeri 3 Surakarta terdapat di 2 cabang, cabang yang pertama terletak di Jl. Prof W.Z. Yohanes (Kerkoff/ Kerkop), dekat dengan Stasiun Jebres, Solo, dan cabang yang kedua terletak di JL. Laks. R.E. Matadinata 143 (Warungmiri), dekat dengan Pasar Gedhe, Kota Solo.

Penelitian tentang Pelaksanaan Aktivitas Ekstrakurikuler Paskibra (Pasukan Pengibar Bendera) dalam Upaya Pembentukkan Karakter, Moralitas, dan Menumbuhkan Sikap Nasionalisme Siswa SMA Negeri 3 Surakarta, terdiri dari beberapa poin penting yaitu, berupa deskripsi secara kualitatif dari data hasil penelitian dan juga pembahasan dan analisis dengan teori Fungsionalisme Struktural dari Talcott Parsons menggunakan konsep Adaptation, Goal attainment, Integration, and Latency (A.G.I.L).

Ada banyak sekali program kegiatan ekstrakurikuler di SMA Negeri 3 Surakarta, berbagai program tersebut bertujuan untuk meningkatkan kompetensi serta membangun dan membentuk karakter peserta didik. masing-masing ekstrakurikuler memiliki kelebihan masing-masing dalam mendidik anggotanya melalui kegiatan yang dilakukan. Masing-masing anggota berproses untuk mencapai hasil yang maksimal di setiap ekstrakurikuler yang diikuti. Dalam penelitian ini, peneliti akan membahas mengenai salah satu kegiatan ekstrakurikuler yang berhubungan erat dengan konteks simbol-simbol kenegaraan dan kegiatan yang sangat berpengaruh dalam pembentukkan karakter siswa dan berperan besar dalam menanamkan sikap nasionalisme kepada 
JURNAL MORAL KEMASYARAKATAN - VOL.2, NO.2, DESEMBER 2017 PELAKSANAAN AKTIVITAS EKSTRAKURIKULER PASKIBRA (PASUKAN PENGIBAR BENDERA) DALAM PEMBENTUKKAN KARAKTER, MORAL DAN SIKAP NASIONALISME SISWA SMA NEGERI 3 SURAKARTA

peserta didik, kegiatan ekstrakurikuler tersebut yaitu, Paskibra (Pasukan Pengibar Bendera). Paskibra (Pasukan Pengibar Bendera) di SMA Negeri 3 Surakarta dikenal dengan nama Pasjub (Pasukan Tujuh Belas), nama ini diambil karena lambang dari tanggal 17 yang sangat sarat akan sejarah kemerdekaan Indonesia yaitu 17 Agustus 1945. Dari namanya sendiri hal ini sudah mencirikan khas sikap nasionalisme yang dimiliki oleh ekstrakurikuler Paskibra di SMA Negeri 3 Surakarta. Dalam keanggotaan Pasjub terdapat dari 17 anggota, yang terdiri dari kelas X dan kelas XI sebagai anggota aktif, dan beberapa kelas XII yang bukan sebagai anggota aktif namun berperan sebagai senior yang tugasnya membimbing dan mengarahkan anggota aktif dan bertugas untuk berbagi pengalaman serta membentuk karakter anggota aktif melalui kegiatankegiatan rutin yang dilakukan.

Sesuai dengan rancangan program yang telah disetujui oleh Kepala Sekolah, pelaksanaan program paskibra mengacu pada program yang telah dibuat, antara lain: (1) Melaksanakan kegiatan rutin pada hari-hari yang telah ditentukan; (2) Upacara Hari Senin merupakan kegiatan rutin yang dilaksanakan setiap Hari Senin yang wajib diikuti oleh staf-staf sekolah beserta seluruh siswa SMA Negeri 3 Surakarta; (3) Upacara hari-hari besar Nasional, kegiatan ini dilaksanakan di dalam lingkungan sekolah ataupun di luar lingkungan sekolah; (4) Perlombaan paskibra, SMA Negeri 3 Surakarta mendapatkan prestasi yang membanggakan, kerjasama antara pihak sekolah, pembimbing, pelatih, dan juga siswa-siswi sangat kompak dan solid; (5) Pelaksanaan HUT RI, sama halnya dengan upacara hari-hari besar nasional yang menjadi petugas upacara adalah siswa-siswi yang mengikuti ekstrakurikuler paskibra di sekolah; (6) Pengadaan seragam, kegiatan ini rutin dilakukan setiap tahun sekali, pengadaan seragam ini dilakukan dengan tujuan kekompakan dan keserasian siswa; (7) Latihan gabungan paskibra yang merupakan program yang diracang oleh SMA Negeri 3 Surakarta; (8) Pelaksanaan formasi, anggota pasukan pengibar bendera dituntut untuk mampu berkreasi membuat formasi dengan bimbingan pelatih; (9) Pelaksanaan kegiatan bakti sosial yaitu dengan memberikan sumbangan berupa dana, buku-buku, atau pakaian bekas kepada warga yang tidak mampu dan anak yatim piatu; (9) Kegiatan outbond yang membantu melatih mental anggota; dan lain sebagainya. Setiap pelaksanaan kegiatan paskibra diatas akan membawa pengaruh terhadap siswa yaitu, membangun rasa persatuan dan kesatuan, keakraban serta kekeluargaan antar siswa, melatih 
JURNAL MORAL KEMASYARAKATAN - VOL.2, NO.2, DESEMBER 2017 PELAKSANAAN AKTIVITAS EKSTRAKURIKULER PASKIBRA (PASUKAN PENGIBAR BENDERA) DALAM PEMBENTUKKAN KARAKTER, MORAL DAN SIKAP NASIONALISME SISWA SMA NEGERI 3 SURAKARTA

disiplin, bertanggung jawab, menggalang sikap kepemimpinan, serta membina kekompakan dan kerja sama, serta menumbuhkan jiwa nasionalisme, dan lain sebagainya.

Peneliti menggunakan teori fungsionalisme struktural dari Talcott Parsons, dengan konsep A.G.I.L-nya. Dari keseluruhan konsep A.G.I.L milik Talcott Parsons, sangat berhubungan erat dengan permasalahan yang diangkat oleh peneliti di dalam penelitian ini. Dari hasil penelitian dan pemaparan secara deskriptif dari pembahasan di atas, maka peneliti selanjutnya melakukan analisis pembahasan dengan kajian teori struktural fungsional dengan konsep A.G.I.L dari Talcott Parsons. Pertama, konsep Adaptation atau yang dikenal dengan adaptasi, di mana terdapat penyesuaian individu di dalam kegiatan ekstrakurikuler Paskibra di sekolah, sehingga individu atau siswa harus menyesuaikan dengan sistem atau dalam hal ini mampu beradaptasi dengan segala hal yang terdapat di dalam kegiatan ekstrakurikuler Paskibra. Kedua, Goal attainment atau pencapaian tujuan, di mana setiap individu yang tergabung di dalam kegiatan ekstrakurikuler Paskibra di sekolah memiliki visi dan misi ataupun tujuan yang ingin dicapai secara bersama-sama. Ketiga, Integration atau integrasi, di mana di dalamnya terdapat penyatuan unsur-unsur berbeda menjadi atau yang menghasilkan pola dan memiliki keserasian fungsi, sehingga siswa sama-sama dibentuk dengan kesamaan perilaku melalui persatuan di dalam keanggotaan Paskibra. Keempat, Latency atau yang dikenal dengan pemeliharaan pola, di mana di dalamnya terdapat istilah menjaga serta mempertahankan norma-norma dan nilai-nilai di dalam ruang lingkup tertentu, hal ini berkaitan dengan penanaman pola bagi setiap individu di dalam kegiatan ekstrakurikuler Paskibra agar tercipta keteraturan sesuai dengan sistem dan pola yang telah ada.

Namun, peneliti lebih memandang pada satu sudut pandang tertentu yang menjadikan penekanan dalam pembuktian dari penelitian ini dengan memfokuskan kepada salah satu konsep A.G.I.L yaitu, Latency atau pemeliharaan pola. Alasan peneliti memilih konsep Latency yaitu, karena di dalam ekstrakurikuler Paskibra terdapat pola yang dipelihara yang sudah ada sebelumnya dan diterapkan secara statis oleh sistem kepada keanggotaan Paskibra. Jadi, setiap individu di dalamnya memiliki kesamaan tujuan dan pola kegiatan dan terus ditanamkan pada generasi yang selanjutnya. Dalam hal ini, berarti terdapat pola-pola yang dipelihara di dalam kegiatan Paskibra yang diaplikasikan melalui aktivitas ekstrakurikuler Paskibra di sekolah. 
JURNAL MORAL KEMASYARAKATAN - VOL.2, NO.2, DESEMBER 2017 PELAKSANAAN AKTIVITAS EKSTRAKURIKULER PASKIBRA (PASUKAN PENGIBAR BENDERA) DALAM PEMBENTUKKAN KARAKTER, MORAL DAN SIKAP NASIONALISME SISWA SMA NEGERI 3 SURAKARTA

Selain itu, peneliti juga mengkaitkan dengan konsep pemikiran Parsons antara sistem sosial dan para aktor yang nantinya terdiri dari status dan peran di dalam sistem sosial. Di dalam sistem sosial, Parsons mengemukakan dua konsep yaitu, antara ego dan alter ego. Ego yang berarti suatu tindakan yang dilakukan individu pada ruang lingkup tertentu karena kesadaran pribadi. Sedangkan, alter ego yang berarti suatu tindakan yang dilakukan individu bukan karena kesadaran pribadi, melainkan karena adanya pengaruh dari sistem sosial di dalam ruang lingkup tertentu, artinya individu melakukannya atas dasar pembentukan dari sistem sosial yang mengharuskan dia melakukan hal yang seharusnya dilakukan, artinya kita harus mengikuti sistem dan bukan atas dasar kehendak kita sendiri.

Selanjutnya, konsep yang lain yaitu, para aktor di dalam sistem sosial, yaitu terdapat peran dan fungsi masing-masing individu di dalam sistem sosial. Terjadi pemindahan norma-norma dan nilai-nilai suatu sistem kepada para aktor di dalam sistem itu sesuai dengan peran dan status yang dimiliki masing-masing individu di dalamnya. Dalam proses sosialisasi yang berhasil, norma-norma dan nilai-nilai diinternalisasikan, yakni norma-norma dan nilai-nilai itu menjadi bagian dari "suara hati" para aktor, di mana pada akhirnya akan menciptakan suatu pembentukkan karakter, moralitas, dan sikap nasionalisme yang kuat pada setiap aktor yang terlibat di dalamnya.

Kegiatan ekstrakurikuler Paskibra memiliki beberapa indikator yang di dalamnya tercermin sikap nasionalisme, karakter yang kuat, serta moralitas yang tinggi, di antaranya: mengenai keaktifan siswa dalam kegiatan Paskibra; mengenai alasan keikutsertaan (ikut terlibat dalam kegiatan Paskibra karena atas dasar keinginan yang kuat dari diri pribadi); terkait status keanggotaan; ikhlas; giat; disiplin; serta mengenai aktivitas siswa di dalam Paskibra. Beberapa indikator tersebut mencerminkan pembentukkan karakter positif dari siswa, baik secara moral maupun secara sikap. Setiap siswa dalam keanggotaan Pasukan Tujuh Belas (Pasjub), memiliki keaktifan yang tinggi, hal ini karena terdapat didikan yang ketat dalam pelaksanaan Pasukan Pengibar Bendera (Paskibra) di SMA Negeri 3 Surakarta. Sekali anggota melakukan penyimpangan atau tidak aktif tanpa alasan yang jelas, amak keanggotaan akan langsung dinonaktifkan sebagai anggota tetap Pasukan Tujuh Belas (Pasjub). Hal ini juga mencerminkan tingkat disiplin yang tinggi. Karena bagaimanapun SMA Negeri 3 Surakarta merupakan salah satu sekolah dengan Pasukan Pengibar Bendera (Paskibra) dengan kiprah yang baik di Kota 
JURNAL MORAL KEMASYARAKATAN - VOL.2, NO.2, DESEMBER 2017 PELAKSANAAN AKTIVITAS EKSTRAKURIKULER PASKIBRA (PASUKAN PENGIBAR BENDERA) DALAM PEMBENTUKKAN KARAKTER, MORAL DAN SIKAP NASIONALISME SISWA SMA NEGERI 3 SURAKARTA

Surakarta. Maka untuk tetap mempertahankan status tersebut, sekolah menerapkan disiplin yang tinggi untuk aktivitas di dalam kegiatan Pasukan Pengibar Bendera (Paskibra) di SMA Negeri 3 Surakarta yaitu, Pasukan Tujuh Belas (Pasjub). Selain untuk citra sekolah, hal ini juga untuk kepentingan dari para anggota Pasjub, yaitu sebagai ajang dalam persaingan dalam meraih prestasi. Dengan begitu, setiap keanggotaan dalam Pasjub memiliki orientasi yang sama dan satu tujuan, yaitu, demi nama baik sekolah, sekaligus untuk mengharumkan nama generasi muda bangsa Indonesia dengan prestasi. Setiap anggota menjalani statusnya sebagai anggota Pasjub dengan rasa bangga, karena Pasjub merupakan salah satu ekstrakurikuler bergengsi di SMA Negeri 3 Surakarta, sehingga persaingan untuk menjadi anggota sangatlah ketat, karena hanya terdapat 17 anggota saja yang lolos setiap kali perekrutan anggota. Jadi, anggota yang terpilih adalah anggota yang benar-benar mencerminkan kriteria Pasukan Pengibar Bendera (Paskibra) yang sesuai harapan untuk membawa nama baik sekolah SMA Negeri 3 Surakarta. Jadi, dengan menyandang status anggota aktif dalam Pasjub akan memberikan perasaan bangga tersendiri bagi para anggotanya, maka akan dengan senang hati para anggota berupaya semaksimal mungkin untuk mempertahankan status keaktifannya tersebut, dengan menjalaninya dengan ikhlas, giat, sehingga hal ini menciptakan suasana atau atmosfer tersendiri dalam aspek kedisiplinan anggota.

Selain itu, ada beberapa hal yang meningkatkan percaya diri setiap anggota Pasukan Tujuh Belas (Pasjub) dan menciptakan rasa bangga, ketika para anggota sedang bertugas, mereka akan sangat bangga dengan menyandang seragam Pasukan Pengibar Bendera (Paskibra), dan dalam prosesi pengibaran bendera pada setiap kali kegiatan upacara bendera, atau pada event-event tertentu yang mewakili sekolah, baik dalam kancah regional maupun nasional. Terdapat kepuasan batin tersendiri bagi setiap anggota. Bayaran untuk setiap perjuangan mereka tidak lain dan tidak bukan adalah sebuah prestasi yang diimpikan. Setiap anggota yang tergabung di dalam Pasjub adalah orang-orang yang sudah siap akan konsekuensi yang dihadapi dan secara sadar memiliki orientasi yang jelas. Hal ini yang secara sadar maupun tidak, bahwa aktivitas di dalam setiap kegiatan ataupun event Pasukan Tujuh Belas (Pasjub) sebagai Pasukan Pengibar Bendera (Paskibra) yang mewakili SMA Negeri 3 Surakarta, mampu membentuk karakter positif, meningkatkan moralitas yang kuat, dan menumbuhkan sikap nasionalisme yang tinggi. Karena setiap anggota tidak hanya mementingkan kepentingan pribadi saja, melainkan untuk 
JURNAL MORAL KEMASYARAKATAN - VOL.2, NO.2, DESEMBER 2017 PELAKSANAAN AKTIVITAS EKSTRAKURIKULER PASKIBRA (PASUKAN PENGIBAR BENDERA) DALAM PEMBENTUKKAN KARAKTER, MORAL DAN SIKAP NASIONALISME SISWA SMA NEGERI 3 SURAKARTA

kepentingan kelompok, jiwa korsa sesama Pasjub, dan orientasi terhadap torehan prestasi. Di dalam setiap anggota Pasukan Tujuh Belas (Pasjub) memiliki beberapa indikator sikap yang tercermin dan terbentuk yaitu, antara lain: pemahaman mengenai sikap nasionalisme yang tinggi; rasa cinta tanah air; memiliki respect yang tinggi terhadap setiap simbol-simbol kebangsaan ataupun atribut-atribut bangsa (Bendera Merah Putih, Pancasila, dan segala sesuatu yang mencerminkan Bangsa Indonesia); memiliki sikap toleransi yang tinggi, karena memiliki dasar pengetahuan yang tertanam kuat untuk setiap anggota Pasjub tentang Kebhinekaan, tentang keberagaman, tentang masyarakat multikultural Bangsa Indonesia dengan segenap sikap pluralismenya, yang dihayati secara bersama-sama dalam keanggotaan Pasukan Pengibar Bendera; memiliki rasa bangga terhadap peran, menjalankan segenap aktivitas, dan semangat yang tinggi dalam keanggotaan di dalam Pasukan Tujuh Belas (Pasjub). Secara tidak langsung beberapa hal tersebut yang turut memberikan sumbangan dalam pembentukkan karakter yang khas dari para anggota Pasukan Tujuh Belas (Pasjub), dan memiliki moralitas yang tinggi, dan jiwa nasionalisme yang tertanam kuat dalam setiap individu maupun kelompok di dalamnya.

Sesuai dengan konsep moralitas yang ditawarkan oleh Emile Durkheim, bahwa ada tiga hal yang menjadi titik tekan dalam pembentukkan moralitas seseorang, antara lain: disiplin; kolektif; dan Otonom. Disiplin dalam arti sikap yang tercermin, kolektif dalam arti memiliki orientasi pada tujuan bersama, dan otonom dalam arti setiap individu memiliki orientasi yang secara sadar dan secara individu yang utuh dalam mengaktualisasikan dirinya secara nyata dan sesuai yang diharapkan. Selain itu, hal ini juga sejalan dengan teori yang diungkapkan oleh Talcott Parsons yaitu, Fungsionalisme Struktural, dengan konsep A.G.I.L-nya, di mana terdapat proses Adaptation (adaptasi), Goal attainment (pencapaian tujuan), Integration (integrasi), dan Latency (pemeliharaan pola). Proses adaptasi yang dilakukan baik dari segi kebijakan yang diterapkan oleh sekolah terhadap ekstrakurikuler Pasukan Tujuh Belas (Pasjub) dan diimplementasikan dalam setiap aktivitasnya sebagai suatu kurikulum yang setiap indikatornya harus terinternalisasi dalam setiap anggota. Adaptasi dilakukan secara dua arah, baik dari pemberi (komunikator), maupun penerima (komunikan). Komunikator adalah instruktur/ pelatih atau orang-orang yang terlibat dalam proses pendidikan dalam Pasukan Tujuh Belas (Pasjub), dan komunikan adalah penerima (anggota Pasjub) dari setiap sesi mentoring maupun dalam proses pendidikan berlangsung. Selain itu, terdapat orientasi tujuan bersama, dan hal ini yang kemudian 
JURNAL MORAL KEMASYARAKATAN - VOL.2, NO.2, DESEMBER 2017 PELAKSANAAN AKTIVITAS EKSTRAKURIKULER PASKIBRA (PASUKAN PENGIBAR BENDERA) DALAM PEMBENTUKKAN KARAKTER, MORAL DAN SIKAP NASIONALISME SISWA SMA NEGERI 3 SURAKARTA

menciptakan atmosfer tersendiri di dalam setiap aktivitas yang dilakukan. Semuanya terintegrasi dalam satu wadah yaitu, Pasukan Tujuh Belas (Pasjub) sebagai arena dalam mewujudkan citacita bersama, saling mengokohkan, saling mengisi, dan saling melengkapi satu sama lain. Sehingga, semuanya berjalan secara struktural dan sesuai dengan peran dan fungsinya masingmasing, yang pada akhirnya terpola sebagai sebuah sistem yang utuh dan terarah, yang pada akhirnya tercipta suatu pemeliharaan pola di dalamnya.

\section{PENUTUP}

\section{Simpulan}

Hasil penelitian menunjukkan bahwa kegiatan ekstrakurikuler paskibra memberikan pengaruh terhadap pembentukan karakter, moralitas, dan sikap siswa karena paskibra dapat menanamkan sikap tegas, bertanggungjawab, disiplin, percaya diri, sikap toleransi yang tinggi dan memiliki jiwa kepemimpinan. Selain itu, di dalam setiap pelaksanaan program kegiatan ekstrakurikuler paskibra dapat menumbuhkan aspek sikap nasionalisme yakni, cinta tanah air, rela berkorban, persatuan dan kesatuan, wawasan kebangsaan (terkait empat pilar bangsa yaitu, "Pancasila, Undang-Undang Dasar 1945, Bhineka Tunggal Ika, dan Negara Kesatuan Republik Indonesia/ NKRI", sikap pluralisme, dan moralitas yang baik), serta jiwa pembaharu atau pantang menyerah. Sehingga siswa-siswi SMA Negeri 3 Surakarta dapat mengemban rasa bangga akan cinta tanah air dan nasionalisme yang bertumpu pada 4 pilar bangsa (UUD 1945, Pancasila, Bhinneka Tunggal Ika, dan NKRI), serta 3 pilar lainnya seperti, Bendera, Bahasa, dan Lagu Kebangsaan. Khususnya pemahaman mengenai nilai-nilai yang terkandung di dalam pancasila sebagai pedoman hidup bangsa Indonesia.

\section{Rekomendasi}

Adapun saran yang dapat peneliti sampaikan pada kesempatan ini yaitu, bahwa peserta didik merupakan asset Negara yang kelak menjadi agen-agen yang akan meneruskan cita-cita para pendahulunya dalam pembangunan bangsa ke arah yang lebih baik. Melalui pendidikanlah semua itu dapat terwujud, maka dari itu peran dari berbagai pihak yang terkait, baik itu keluarga, masyarakat, sekolah, berbagai stakeholders, dan juga pemerintah, perlu dimaksimalkan peranan dan kinerja masing-masing serta mendorong peserta didik untuk bisa menjadi sosok pemuda 
JURNAL MORAL KEMASYARAKATAN - VOL.2, NO.2, DESEMBER 2017 PELAKSANAAN AKTIVITAS EKSTRAKURIKULER PASKIBRA (PASUKAN PENGIBAR BENDERA) DALAM PEMBENTUKKAN KARAKTER, MORAL DAN SIKAP NASIONALISME SISWA SMA NEGERI 3 SURAKARTA

yang memiliki jiwa-jiwa nasionalisme, berkarakter kuat dan cerdas, bermoral, berakhlak mulia, berwawasan luas, dan berkepribadian yang baik. Semoga karakter positif, moralitas, dan sikap nasionalisme dapat tetap tertanam kuat dalam diri peserta didik dan para pemuda di Indonesia sebagai "agen of change", bukan hanya melalui kegiatan ekstrakurikuler paskibra, akan tetapi juga melalui berbagai hal yang digelutinya.

\section{DAFTAR RUJUKAN}

Arikunto, Suharsimi. (2007). Metode Penelitian Sosial. Jakarta: TP Rineka Cipta.

Bungin, Burhan. (2005). Metode Penelitian Kuantitatif. Jakarta: Kencana. . (2015). Metode Penelitian Kuantitatif. Jakarta: Kencana.

Depdikbud. (1978). Pola Dasar Pembinaan dan Pengembangan Generasi Muda. Jakarta: Depdikbud.

Durkheim, Emile. (1922). Education et Sociologie. Paris: Felix Alcan. . (1925). L'education morale. Paris: Libraire Felix Alcan.

- (1970). Pendidikan Moral-Suatu Studi Teori dan Aplikasi Sosiologi Pendidikan. Jakarta: Penerbit Erlangga. . (1997). The Division of Labor in Society. New York: The Free Press.

Mediawan, Andro. (2012). Ragam Ekskul. Jakarta: Buku Biru.

Musa, Ali Maskur. (2010). Nasionalisme Di Persimpangan. Jakarta: Erlangga.

Omensen, Sinamo. (2012). Pendidikan Kewarganegaraan. Jakarta: Permata Aksara.

Peraturan Menteri Pendidikan dan Kebudayaan Republik Indonesia Nomor 62 Tahun 2014 Tentang Pengertian Ekstrakurikuler.

Ritzer, George. (2012). Teori Sosiologi - Dari Sosiologi Klasik Sampai Perkembangan Terakhir Postmodern. Yogyakarta: Pustaka Pelajar.

Santoso, Djoko. (2014). Menggagas Indonesia Masa Depan. Jakarta: Tebet Center 66. Sugiyono. (2010). Metode Penelitian Kuantitatif, Kualitatif dan $R \&$ D. Bandung: ALFABETA. Suripto, Sakinah Meindahsari. (2015). Pelaksanaan Ekstrakurikuler Paskibra (Pasukan Pengibar Bendera) dalam Upaya Menumbuhkan Sikap Nasionalisme Siswa di SMP Negeri 3 Malang. Jurnal HKN FIS UM, 3 (6), ISSN: 2337-5205. Diperoleh 5 Oktober 2016, dari http://skripsihknum.org. 